Pastor, Peter. "Vörös, Boldizsár 2014: Történelemhamisítás és politikai propaganda. Illés Béla elmeszüleményei a magyar szabadságküzdelmek orosz támogatásáról ('Falsification of History and Political Propaganda - The Brainchildren of Béla Illés about the Russian Support of Hungarian Struggles for Freedom'). Budapest: Magyar Tudományos Akadémia (MTA) Bölcsészetudományi Kutatóközpont. Történettudományi Intézet, 2014.335 pp.” Hungarian Cultural Studies. e-Journal of the American Hungarian Educators Association, Volume 8 (2015): http://ahea.pitt.edu DOI: 10.5195/ahea.2015.199

\title{
Vörös, Boldizsár 2014: Történelemhamisítás és politikai propaganda. Illés Béla elmeszüleményei a magyar szabadságküzdelmek orosz. támogatásáról ('Falsification of History and Political Propaganda - The Brainchildren of Béla Illés about the Russian Support of Hungarian Struggles for Freedom'). Budapest: Magyar Tudományos Akadémia (MTA) Bölcsészetudományi Kutatóközpont. Történettudományi Intézet, 2014. 335 pp.
}

\author{
Reviewed by Peter Pastor, Montclair State University
}

As a Hungarian elementary school pupil during the early 1950s I first became acquainted with the story of the 1849 "martyrdom" of Russian officer Aleksei Gusev through an assigned school reader. The reader selection was based on a short story of journalist and author Béla Illés titled "A Guszev-ügy" ('The Gusev Affair'). According to Illés, the story was based on facts and described how Captain Gusev and his fifteen comrades turned against the ongoing Russian intervention in the 1848-49 Hungarian War of Liberation, an intervention that ultimately caused Hungary's defeat. According to the story, the conspirators, while on their way to Hungary with the tsarist army, in fact engaged in a propaganda campaign in favor of the Hungarian revolutionaries. They were arrested, charged with treason and tried before a military court in Minsk. Seven of them, including their leader Captain Gusev, were sentenced to death by hanging, and the execution took place on August 16, 1849. The rest of the conspirators were exiled to Siberia.

I recall that as a child living under the communist dictatorship of Mátyás Rákosi, which was backed by the occupying Soviet forces, the story left a deep impression on me. Of course I did hear about the looting by the Soviet troops after the liberation from the Nazi occupiers and their Hungarian Arrow Cross henchmen, but my personal experience was that the Russian soldiers treated children, myself included, well. They were friendly and jovial, taking my brother and me to pastry shops; another time a group of soldiers took us with them on a roller-coaster ride in the City Park. Reading the Gusev story as a child reinforced my belief that there had been good Russian soldiers who had sympathized with the Hungarians at the time when the invading Russian army crushed the 1848-49 Hungarian Revolution. However, from Boldizsár Vörös' examination of the history of the invention and afterlife of the Gusev affair I now learned that the goal of the inclusion of Illés' story in elementary school textbooks was to impress upon the "new generation" the validity of a falsified historic event and thus emphasize the tradition of SovietHungarian friendship (148). In my case as a young Hungarian pupil, the goal of the textbook publishers was achieved, but soon afterward the events of 1956 changed all that.

(cc) BY

ULLS D-Serle
New articles in this journal are licensed under a Creative Commons Attribution 4.0 International License.

This journal is published by the University Library System of the University of Pittsburgh as part of its D-Scribe Digital Publishing Program and is cosponsored by the University of Pittsburgh Press 
Pastor, Peter. "Vörös, Boldizsár 2014: Történelemhamisítás és politikai propaganda. Illés Béla elmeszüleményei a magyar szabadságküzdelmek orosz támogatásáról ('Falsification of History and Political Propaganda - The Brainchildren of Béla Illés about the Russian Support of Hungarian Struggles for Freedom'). Budapest: Magyar Tudományos Akadémia (MTA) Bölcsészetudományi Kutatóközpont. Történettudományi Intézet, 2014.335 pp.” Hungarian Cultural Studies. e-Journal of the American Hungarian Educators Association, Volume 8 (2015): http://ahea.pitt.edu DOI: 10.5195/ahea.2015.199

Vörös ties the invention of the Gusev narrative to the need of the post-1945 Hungarian communist politics to create a hero who could be part of the so-called "progressive traditions" intended to smooth the way for the Soviet occupation and subsequent communist takeover of Hungary. During the war, Béla Illés, a Hungarian communist, was an officer in the Soviet army. He was a contributor to Igaz Szó, published for the Hungarian prisoners of war in the Soviet Union. In 1945 he became Editor in Chief of the occupying Soviet army's Hungarian-language newspaper Új Szó. He used these publications as vehicles to falsify history and create a façade of a Russian-Hungarian cooperation that had allegedly existed as early as the eighteenth and nineteenth centuries.

While the major part of the book deals with the Gusev narrative, Vörös begins his work with a discussion of Illés' writings on the relations between Tsar Peter the Great and Prince Ferenc II Rákoczi, the leader of the Hungarian war of liberation against the Habsburg Monarchy, which lasted from 1703 to 1711. Illés published his first article on the topic under the title "Pásztortűz a Verhovinán" ('Watch Fire on the Verkhovyna') in the April 25, 1944 issue of Igaz. Szó. Although Peter and Rákoczi did sign an alliance in 1707, it had no meaningful outcomes for the war that lasted from 1703-1711.Yet Illés went on to present a picture wherein the Russians supported the uprising from its beginning to its end. To back his claim Illés even referred to nonexistent documents, including the invented diary of a nonexistent military officer, Yegor Morozov. Vörös rightly points out that Illés' claim was a falsification of history with the propagandistic purpose of showing that the roots of Soviet support for Hungarian freedom could be found already in the early 1700s. In reality, though, historical evidence indicates that in 1704 the tsar offered the Habsburg emperor 30,000 troops to crush the Hungarian "rebels" (see Peter Pastor, "Peter the Great and Prince Ferenc II Rákoczi," The Place of Russia in Europe. Ed. Gyula Szvák; Budapest: Magyar Ruszisztikai Intézet, 1999, 212). While in the Peter I-Rákoczi narrative there were some elements of truth, Vörös stresses that the history of the Gusev affair was completely false and that it was none but an invention of Illés' fertile mind, a mind so fertile and devious that it referred to non-existing documents in order to make a claim of truth. The first version of the Gusev story appeared in the February 1, 1945 issue of Új Szó, and was followed by some slightly corrected versions, including one which Illés called a fictionalized short story.

Vörös points out that the communist establishment turned Gusev into a cult figure and that for five years following the publication of Illés' first version even Hungarian historians accepted the Gusev affair as a genuine part of the past. The invention's spread in secondary sources can easily be explained: one historian footnoted references about Gusev from another historian's work and others probably followed. Naturally, nobody referenced the original documents as they existed only in the mind of Béla Illés. Soviet historians soon jumped on the bandwagon and went on to include the Gusev affair in their own monographs and articles about the 1848-49 Hungarian Revolution and the tsarist intervention.

Based on the decision of the Communist Party's Central Committee, on the centenary of the alleged martyrdom of Gusev and his co-conspirators, a major street in central Budapest, Sas utca ('Eagle Street') that ended near the American Legation on Szabadság tér ('Freedom Square'), was renamed Guszev utca ('Gusev Street'). In addition, a memorial plaque was placed on the wall of the Ministry of Heavy Industry on the corner of Guszev utca and Szabadság tér. The relief depicts Captain Gusev as he attempts to protect with his own body the Hungarian freedom 
Pastor, Peter. "Vörös, Boldizsár 2014: Történelemhamisítás és politikai propaganda. Illés Béla elmeszüleményei a magyar szabadságküzdelmek orosz támogatásáról ('Falsification of History and Political Propaganda - The Brainchildren of Béla Illés about the Russian Support of Hungarian Struggles for Freedom'). Budapest: Magyar Tudományos Akadémia (MTA) Bölcsészetudományi Kutatóközpont. Történettudományi Intézet, 2014.335 pp.” Hungarian Cultural Studies. e-Journal of the American Hungarian Educators Association, Volume 8 (2015): http://ahea.pitt.edu DOI: 10.5195/ahea.2015.199

fighters from the bayonets of advancing tsarist troops; and the inscription reads: "To the memory of the martyred Captain Gusev and his comrades who turned against the tsarist autocracy fighting together with our people's freedom fighters. Placed [on the wall] by the Hungarian People's Army, August 16, 1949." Clearly, the relief was designed to provide an iconic, sacred memorial and a site to practice another communist ritual. While Vörös suggests in his monograph that the invention of the tradition began when the Gusev story was first published in 1945, it makes more sense to assume that it began in 1949 and developed as the invention through the relief gained a ritualistic or symbolic value following the consecration speech at the relief's unveiling, which was given by Lieutenant General Gusztáv Illy, superintendent of the army (a position which Vörös for some reason does not specify). The general went on to proclaim that the relief provided a lasting memorial so the Hungarians should never forget the "martyred son of the Russian people who died for Hungarian freedom" (173). Furthermore, Vörös points out that Illy's speech legitimized the communist status quo in Hungary by harking to the past as Illy declared that in the twentieth century the common history of the Russians and Hungarians made both nations "defenders of freedom against the imperialist oppressors" (173).

The obligatory glorification of the Soviet Union "led by the great Stalin" was also part of Illy's speech as he pledged in the name of the Hungarian nation to continue the common struggle until the final victory (174). The irony of that speech, however, seems to have escaped Boldizsár Vörös, who fails to note that a year later, almost to the day, on August 17, 1950 Illy was sentenced to death following a show trial in which he was one of a group of generals falsely accused of treason and of spying for the very same "imperialists" that he had denounced a year earlier. If Gusev's story was invented, so was Illy's guilt, and both reflected the totalitarian nature of the communist state.

Concerning the origin of the Rákoczi and Gusev stories, it is not explained nor guessed by Vörös who gave the green light for the original publication of the Illés stories; but since both Hungarian-language papers in which these articles appeared were Soviet publications, prepublication instructions and their approval had to come not from the Hungarian communists, as Vörös implies, but from persons in the Soviet political hierarchy.

A more detailed description of the post-1945 political atmosphere in Hungary that included the purges would have made it clearer why the serious questioning of Illés' tall tales began only following Stalin's death in 1953, during the Soviet and Hungarian thaw. The names of the personages mentioned in the book are familiar to the author, but it would have been desirable to identify them in some detail either in the text or in the footnotes. Such information could have clarified not only the issues around General Illy but the behavior of others as well. For example, it would have been more understandable why as late as the spring of 1987 the Dean of historians, Domokos Kosáry, was concerned about retaliation by the authorities when he pointed out the "fictive aspects" of the Russian support for the Rákoczi War of Liberation, and of the Gusev affair (141). Following the crushing of the 1956 Revolution by Soviet troops Kosáry was sentenced to two years in prison for acting as the President of the Revolutionary Council of the Historical Institute of the Hungarian Academy of Sciences during the brief life of the uprising. In light of his experience with retribution, it is not surprising that Kosáry was careful about how to call and describe the communist falsification of history. 
Pastor, Peter. "Vörös, Boldizsár 2014: Történelemhamisítás és politikai propaganda. Illés Béla elmeszüleményei a magyar szabadságküzdelmek orosz támogatásáról ('Falsification of History and Political Propaganda - The

Brainchildren of Béla Illés about the Russian Support of Hungarian Struggles for Freedom'). Budapest: Magyar Tudományos Akadémia (MTA) Bölcsészetudományi Kutatóközpont. Történettudományi Intézet, 2014.335 pp.” Hungarian Cultural Studies. e-Journal of the American Hungarian Educators Association, Volume 8 (2015): http://ahea.pitt.edu DOI: 10.5195/ahea.2015.199

Notwithstanding the aforementioned shortcomings, the book provides for excellent reading. Boldizsár Vörös, who before the appearance of this publication wrote over a dozen articles on the topic, did a masterful job in creating a definitive synthesis of these essays. The full monograph successfully details the rise and fall of a communist "invented tradition" even before the collapse of communism in Hungary. 